\title{
Utilization of Pre-travel Health Services Among Kenyan International Travelers in Jomo Kenyatta Airport Conducted From 2nd August to 30th September 2017
}

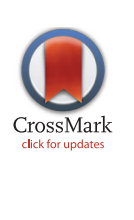

\author{
Grace Wacuka Kihika ${ }^{1 *}$, Eddy Okoth Odari ${ }^{1}$, Joseph Mutai ${ }^{2}$, Augustine Gatimu Njuguna ${ }^{3}$ \\ ${ }^{1}$ College of Health Sciences, Jomo Kenyatta University of Agriculture and Technology, Nairobi, Kenya \\ ${ }^{2}$ Kenya Medical Research Institute, Nairobi, Kenya \\ 3 School of Health Sciences, Kenyatta University, Nairobi, Kenya
}

Corresponding Author: Grace Wacuka Kihika, MSc Student, College of Health Sciences, Jomo Kenyatta University of Agriculture and Technology, Nairobi, Kenya. Tel: +254-714652313,Email: gracewacuka96@gmail.com

Received June 11, 2018; Accepted August 8, 2018; Online Published September 25, 2018

\begin{abstract}
Introduction: The geographical movement of people from one area to another poses the threat of transmission of infectious diseases. Kenya is among the vulnerable countries when it comes to disease transmission, because it is a major transport hub in East Africa, yet data on the availability and uptake of pre-travel health services is limited.

Methods: A cross-sectional descriptive study was conducted to determine the uptake of pre-travel health services. The systematic sampling method was used to obtain a sample size of 384 travelers among those in the waiting lounge prior to departure; four key informants were chosen purposively. A self-administered questionnaire was used for data collection. The results of data analysis are presented in the form of tables, graphs, charts, and text.

Results: The majority of respondents (70.6\%) knew of at least one health service offered to international travelers in Kenya. The most sought-after pre-travel health service was vaccination (70.97\%), but very few (13.93\%) travelers sought pre-travel health advice on how to stay healthy while abroad. The majority of travelers were positive about pre-travel health services. The Port Health Department focuses more on the health of international arrivals as opposed to departures; there are no functional travel health clinics.

Conclusion: The results indicated that the government pays little attention to departing international travelers. Therefore, it is important for the government to develop policies, guidelines, and structures that will ensure that pre-travel health services are received by travelers prior to departure. Travel clinics need to be set up to increase the uptake of pre-travel health services. Moreover, further research should be conducted.
\end{abstract}

Keywords: Airports, Travel, Health Services, Immunization, Vaccines, Kenya

Citation: Kihika GW, Odari EO, Mutai J, Njuguna AG. Utilization of pre-travel health services among Kenyan international travelers in Jomo Kenyatta airport conducted from 2nd August to 30th September 2017. Int J Travel Med Glob Health. 2018;6(3):110-120. doi:10.15171/ijtmgh.2018.21.

\section{Introduction}

Data provided by the World Tourism Organization indicates that tourism has grown by $500 \%$ globally in the last 25 years. In the year 2014, there were 1.161 billion arrivals registered globally, which was a tremendous increase from 540511 673 arrivals in the year 1995. In Kenya the number of air passengers handled by Kenya Airports Authority increased from 7516000 in 2010 to 8882000 passengers in 2014. More than two-thirds of these passengers traveling by air passed through Jomo Kenyatta International Airport (JKIA). ${ }^{1}$

Although globalization promotes economic development and international travel, it exposes travelers to risks such as malaria and complications of conditions, especially during winter, as well as travelers' diarrhea. $22 \%$ to $62 \%$ of Finish, Scottish, and American travelers have reported health problems dependent on the destination of travel and the season. ${ }^{2}$ Progressive data collection has shown a risk of 3 to 6 cases per 1000 persons per month of staying abroad for hepatitis $\mathrm{A}$, which is the most recurrent type of viral hepatitis. The incidence of travelers' diarrhea varies from $20 \%$ to $50 \%$ in various countries. The most severe consequence of travelassociated risks is death, which occurs in approximately 1 in every 100000 international travelers. ${ }^{3}$ A study among Swedish travelers found that one in every two Swedish travelers to

Copyright (C) 2018 The Author(s). This is an open-access article distributed under the terms of the Creative Commons Attribution License (http:// creativecommons.org/licenses/by/4.0), which permits unrestricted use, distribution, and reproduction in any medium, provided the original work is properly cited. 
tropical and subtropical areas reported some type of travelrelated and, at times, crippling health problem. ${ }^{4}$

\section{Broad Objective}

This study aimed to determine the level of utilization of pretravel health services among Kenyan travelers departing JKIA.

\section{Specific Objectives}

- To evaluate pre-travel health services available for Kenyan international travelers departing JKIA.

- To assess knowledge, attitude, and practices (KAP) regarding pre-travel health services among Kenyan travelers departing JKIA.

- To identify factors associated with the utilization of pretravel health services among travelers departing JKIA.

\section{Methods}

Study Setting

The present study was conducted at JKIA. Data was collected from 2nd August to 30th September 2017. The airport serves an average of 19000 passengers daily with direct flights connecting to Europe, the Middle East, the Far East, and the African Continent. Being an international and the busiest airport in Kenya made JKIA a preferred site for this study due to the possibility of including respondents with different characteristics as well as different travel destinations, hence ensuring both internal and external validity.

\section{Study Design}

This research was a cross-sectional descriptive study among Kenyan international travelers at JKIA.

\section{Study Population}

The study targeted Kenyan travelers departing JKIA who had attained the age of 18 years.

\section{Inclusion Criteria}

Travelers 18 years of age or older;

Travelers willing to participate in the study on a voluntary basis and without any incentive.

\section{Exclusion Criteria}

Travelers who could not read and write English or Kiswahili; Extradited travelers.

\section{Sampling Techniques}

Systematic sampling was employed to choose 384 participants from among Kenyan travelers departing JKIA for other countries. Respondents were recruited from waiting lounges in the departure terminals (Terminals 1A, 1C, and 2). Travelers are expected to be seated in the lounges at airside for 30 minutes to 1 hour before boarding a flight. It was at this point when travelers were waiting that sampling was done. Thirty questionnaires were completed daily until 384 completed questionnaires were obtained. This was divided across all the lounges, which translated to 10 questionnaires from each lounge per day. Data collection was carried out from 2nd August to 30th September 2017. Key informants to be interviewed were purposively selected.

\section{Data Collection}

a. Questionnaire

Data was collected using a self-administered questionnaire distributed by research assistants. The first section of the questionnaire captured the respondent's individual and trip characteristics. The other sections contained questions that were used to assess KAP and examine the utilization of pre-travel health advice among travelers. Respondents were asked to indicate if they pursued health information from specific sources such as the Internet and if they were carrying prescription medication related to the trip prior to travel. The questionnaires were administered in English and Kiswahili, which are the languages of instruction in Kenya. Each questionnaire was evaluated for completeness after the respondents finished filling in the responses.

\section{b. Key Informants}

Key informant interviews were conducted to address issues regarding the availability of pre-travel health services as well as gaps existing during the provision of such services. The 4 key informants interviewed were chosen purposively based on seniority and level of experience.

\section{Validity and Reliability}

Probability sampling was used during selection of the respondents, so each international traveler had an equal chance of getting selected to take part in the study. In addition, a pilot study was conducted prior to commencing the actual study in order to address ambiguous questions and ensure all questions were understood as intended by the researcher. Cronbach $\boldsymbol{\alpha}$ was found to be 0.8 , which signifies good internal consistency.

\section{Data analysis}

Data was analyzed using IBM SPSS 22. Descriptive analysis was performed in the form of percentage distribution, means, mode, standard deviations, and chi-square and inferential: logistic regression. The main responses from the key informant interviews were quoted to respond to the objective regarding availability.

\section{Results}

Demographic Characteristics

Individual Characteristics of Respondents

A total of 384 questionnaires were well completed by participants. The age of the respondents ranged from a minimum of 19 years to a maximum of 74 years with a mean of 37.23 years; the standard deviation from the mean was 10.62 . There were more male (64\%) than female $(36 \%)$ respondents. Of the 384 respondents, $34.1 \%$ were single, $59.1 \%$ were married, $2.9 \%$ lived a celibate life, and $1.8 \%$ were separated, while $2.1 \%$ were divorced. More than half of the respondents were married, while those who were separated were the least in number. Slightly more than one third of all respondents had a degree certificate, while only $0.5 \%$ of all respondents had not attended school at all and $19.3 \%$ of all 
Table 1. Individual Characteristics of Respondents

\begin{tabular}{|c|c|c|c|}
\hline Variables & No. & Mean \pm SD & Min.-Max. \\
\hline \multirow[t]{2}{*}{ Age } & 384 & $37.22917 \pm 10.62116$ & $19-74$ \\
\hline & & Percent & $\begin{array}{c}\text { Cumulative } \\
\text { Percent }\end{array}$ \\
\hline \multicolumn{4}{|l|}{ Gender } \\
\hline Male & 247 & 64.3 & 64.3 \\
\hline Female & 137 & 35.7 & 100.0 \\
\hline \multicolumn{4}{|l|}{ Marital status } \\
\hline Single & 131 & 34.1 & 34.1 \\
\hline Married & 227 & 59.1 & 93.2 \\
\hline Celibate & 11 & 2.9 & 96.1 \\
\hline Separated & 7 & 1.8 & 97.9 \\
\hline Divorced & 8 & 2.1 & 100.0 \\
\hline \multicolumn{4}{|l|}{ Education } \\
\hline $\begin{array}{l}\text { Never attended } \\
\text { school }\end{array}$ & 2 & 0.5 & 0.5 \\
\hline Primary & 7 & 1.8 & 2.3 \\
\hline Secondary & 100 & 26.0 & 28.4 \\
\hline Certificate/Diploma & 62 & 16.1 & 44.5 \\
\hline Degree & 139 & 36.2 & 80.7 \\
\hline Masters & 64 & 16.7 & 97.4 \\
\hline $\mathrm{PhD}$ & 10 & 2.6 & 100.0 \\
\hline
\end{tabular}

respondents had gone for postgraduate studies (Table 1).

\section{Trip Characteristics}

The majority of the respondents were departing to African countries, while the fewest number of respondents were departing to Australia. Of all respondents, $74 \%$ were going to African countries, $10.41 \%$ to the Middle East, $5.73 \%$ to America, $4.17 \%$ to Asia, $3.39 \%$ to Europe, and $1.56 \%$ to Australia. $15.6 \%$ had not traveled before, while the other $84.4 \%$ were not first-time travelers. $54.4 \%$ of respondents started planning for their trip less than a month before their departure date, while $45.6 \%$ planned for their trip more than a month prior to their departure date. $60.2 \%$ of respondents were visiting one country, while $39.8 \%$ were planning to visit more than one country. Half of the respondents were traveling for business or to attend conferences and conventions $(50.5 \%)$. The category with the least number of travelers was that of those traveling for missionary work $(2.3 \%)$. The number of those visiting friends and relatives was almost equal to that of tourists, $13 \%$ and $12.5 \%$, respectively. $40.1 \%$ of the respondents were going out of the country for less than two weeks, $31.3 \%$ for between 2 weeks and three months, and $28.6 \%$ had a trip duration meant to be more than 3 months (Table 2).

Knowledge, Attitude, and Practices of Respondents in Relation to Utilization of Pre-travel Health Advice Knowledge

$70.6 \%$ of the respondents knew of some health services offered to international travelers, while $29.4 \%$ were not aware of any health services offered to international travelers (Figure 1). Of the $70.6 \%$ of respondents who knew services were offered to international travelers, $84.21 \%$ knew of vaccinations, $11.28 \%$ were aware of health advice given to international travelers, and $4.14 \%$ were aware of drugs for self-medication. One
Table 2. Trip Characteristics

\begin{tabular}{|c|c|c|c|}
\hline Trip Characteristics & No. & Percent & $\begin{array}{c}\text { Cumulative } \\
\text { Percent }\end{array}$ \\
\hline \multicolumn{4}{|l|}{ Travel destination } \\
\hline Africa & 287 & 74.74 & 74.74 \\
\hline Middle East & 40 & 10.41 & 85.15 \\
\hline America & 22 & 5.73 & 90.88 \\
\hline Asia & 16 & 4.17 & 95.05 \\
\hline Europe & 13 & 3.39 & 98.44 \\
\hline Australia & 6 & 1.56 & 100.0 \\
\hline \multicolumn{4}{|l|}{ Duration of travel } \\
\hline$<2$ weeks & 154 & 40.1 & 40.1 \\
\hline 2 weeks $-<3$ months & 120 & 31.3 & 71.4 \\
\hline 3 months or more & 110 & 28.6 & 100.0 \\
\hline \multicolumn{4}{|l|}{ Travel group } \\
\hline Traveling alone & 346 & 90.1 & 90.1 \\
\hline Traveling with children ( $<16$ years) & 38 & 9.9 & 100.0 \\
\hline \multicolumn{4}{|l|}{ Visiting 2 or more countries } \\
\hline One & 231 & 60.2 & 60.2 \\
\hline 2 or more & 153 & 39.8 & 100.0 \\
\hline \multicolumn{4}{|l|}{ Duration of planning prior to travel } \\
\hline Less than 1 month & 209 & 54.4 & 54.4 \\
\hline More than 1 month & 175 & 45.6 & 100.0 \\
\hline \multicolumn{4}{|l|}{ History of previous travel } \\
\hline Traveled from home country before & 324 & 84.4 & 84.4 \\
\hline $\begin{array}{l}\text { No history of previous travel from } \\
\text { home country }\end{array}$ & 60 & 15.6 & 100.0 \\
\hline
\end{tabular}

\section{Do you know of any health services offered to international travellers $(n=384)$}

$29.4 \%$
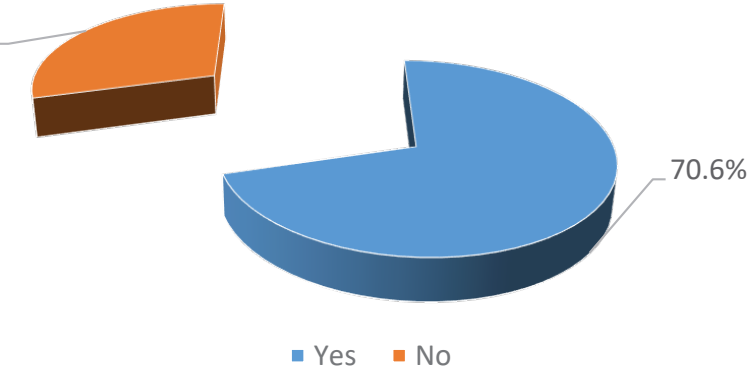

Figure 1. Services Offered to International Travelers That Were Known to Study Participants

traveler talked of full-body medical examinations as part of the services they knew. The majority of the respondents indicated that vaccination is important to avoid health problems as well as challenges at points of entry. It is also noteworthy that $4.9 \%$ of respondents did not know the importance of getting vaccinated at all (Table 4).

The majority of the respondents $(70.83 \%)$ were aware of some existing travel recommendation guidelines, while the other $29.17 \%$ were unaware of any existing travel recommendations or guidelines for yellow fever (Table 5).

As seen in Table 6, 41.1\% of the respondents learned of yellow fever guidelines from the Kenyan government, $24.4 \%$ from the World Health Organization, and 15.9\% from the CDC. Other respondents learned of the guidelines from more 
Table 3. Independent Predictors of Seeking Professional Pre-travel Health Services

\begin{tabular}{|c|c|c|c|c|c|}
\hline & \multirow{2}{*}{ Coefficients } & \multirow{2}{*}{ OR } & \multirow{2}{*}{$P$ Value } & \multicolumn{2}{|c|}{$95 \% \mathrm{CI}$ for $\mathrm{OR}$} \\
\hline & & & & Upper & Lower \\
\hline \multicolumn{6}{|c|}{ Independent Predictors of Seeking Professional Pre-travel Health Services by Traveler's Region of Destination } \\
\hline \multicolumn{6}{|l|}{ Respondent's destination } \\
\hline Africa & -1.898 & 0.150 & 0.034 & 0.026 & 0.868 \\
\hline America & -1.153 & 0.316 & 0.279 & 0.039 & 2.550 \\
\hline Middle East & -0.857 & 0.424 & 0.372 & 0.065 & 2.789 \\
\hline Asia & -2.015 & 0.133 & 0.135 & 0.009 & 1.872 \\
\hline Europe & -0.511 & 0.600 & 0.639 & 0.071 & 5.059 \\
\hline \multicolumn{6}{|c|}{ Independent Predictors of Seeking Professional Pre-travel Health Advice by Age of the Respondent } \\
\hline \multicolumn{6}{|l|}{ Age group of respondent } \\
\hline $18-35$ years & 2.146 & 8.550 & $<0.001$ & 5.380 & 13.587 \\
\hline 36-50 years & 2.595 & 13.400 & $<0.001$ & 7.048 & 25.477 \\
\hline \multicolumn{6}{|c|}{ Independent Predictors of Seeking Professional Pre-Travel Health Advice by Number of Countries Being Visited } \\
\hline \multicolumn{6}{|l|}{ Number of countries being visited } \\
\hline Visiting 1 country & 2.356 & 10.550 & $<0.001$ & 6.670 & 16.688 \\
\hline Visiting more than 1 country & 1.342 & 3.827 & $<0.001$ & 2.576 & 5.678 \\
\hline \multicolumn{6}{|c|}{ Independent Predictors of Seeking Professional Pre-travel Health Advice by Reasons for Travel } \\
\hline \multicolumn{6}{|l|}{ Reason for travel } \\
\hline Visiting friend and relatives & 1.012 & 2.75 & 0.314 & 0.187 & 1.681 \\
\hline Vacation/tourism & 2.805 & 16.53 & 0.094 & 0.109 & 1.098 \\
\hline Business/convention/conferences & 0.004 & 1 & 0.951 & 0.125 & 2.456 \\
\hline Study/research & 0.980 & 2.66 & 0.322 & 0.007 & 1.566 \\
\hline Missionary & 0.093 & 1.09 & 0.760 & 0.107 & 2.005 \\
\hline Medical care/procedure & 2.372 & 10.72 & 0.124 & 0.578 & 1.201 \\
\hline \multicolumn{6}{|c|}{ Independent Predictors of Seeking Professional Pre-travel Health Advice by Length Of Stay } \\
\hline \multicolumn{6}{|l|}{ Length of stay } \\
\hline Less than two weeks & 0.091 & 1.1 & 0.034 & 1.567 & 2.785 \\
\hline Between 2 weeks and 3 months & 1.014 & 2.76 & $<0.001$ & 2.576 & 5.678 \\
\hline More than 3 months & 0.635 & 1.89 & 0.006 & 1.345 & 3.846 \\
\hline \multicolumn{6}{|c|}{ Independent Predictors of Seeking Professional Pre-Travel Health Advice by Marital Status } \\
\hline \multicolumn{6}{|l|}{ Marital status } \\
\hline Single & 2.529 & 12.57 & $<0.001$ & 0.073 & 1.008 \\
\hline Married & 1.200 & 3.32 & 0.002 & 0.001 & 1.065 \\
\hline Celibate & 0.009 & 1 & 0.34 & 0.902 & 2.987 \\
\hline Separated & 0.648 & 1.9 & 0.31 & 0.045 & 1.908 \\
\hline \multicolumn{6}{|c|}{ Independent Predictors of Seeking Professional Pre-travel Health Advice by Education } \\
\hline \multicolumn{6}{|l|}{ Education } \\
\hline Never attended school & 0.183 & 1.2 & 0.105 & 0.089 & 2.067 \\
\hline Primary & 0.331 & 1.4 & 0.201 & 0.109 & 1.987 \\
\hline Secondary & 1.259 & 3.5 & $<0.001$ & 0.000 & 1.009 \\
\hline Certificate/Diploma & 0.007 & 1 & 0.134 & 0.119 & 2.798 \\
\hline Degree & 0.985 & 2.68 & 0.003 & 0.001 & 1.012 \\
\hline Masters & 0.109 & 1.1 & 0.290 & 0.109 & 1.908 \\
\hline \multicolumn{6}{|c|}{ Independent Predictors of Seeking Professional Pre-travel Health Advice by History of Previous Travel } \\
\hline \multicolumn{6}{|l|}{ History of previous travel } \\
\hline History of previous travel & 1.510 & 4.53 & 0.108 & 0.298 & 2.001 \\
\hline No history of previous travel & 1.602 & 4.96 & 0.082 & 0.009 & 2.901 \\
\hline
\end{tabular}

Abbrevaition: OR, odds ratio. 
Table 4. Importance of Pre-travel Services as Perceived by Respondents

\begin{tabular}{lccc}
\hline & No. & Percent & $\begin{array}{c}\text { Cumulative } \\
\text { Percent }\end{array}$ \\
\hline Vaccination & 224 & 84.21 & 84.21 \\
$\begin{array}{l}\text { Health advice on how to stay } \\
\text { healthy depending on destination }\end{array}$ & 30 & 11.28 & 95.49 \\
Drugs for self-medication & 11 & 4.14 & 99.63 \\
Others & 1 & 0.37 & 100.0 \\
Total & 266 & 100.0 & \\
\hline
\end{tabular}

Table 5. Awareness of Existing Travel Recommendations on Yellow Fever $(\mathrm{n}=384)$

\begin{tabular}{|c|c|c|c|}
\hline & No. & Percent & $\begin{array}{l}\text { Cumulative } \\
\text { Percent }\end{array}$ \\
\hline To avoid health problems & 230 & 59.9 & 59.9 \\
\hline To take vaccination & 38 & 9.9 & 69.8 \\
\hline To take prophylaxis & 8 & 2.1 & 71.9 \\
\hline To avoid challenges at point of entry & 41 & 10.7 & 82.6 \\
\hline Don't know & 19 & 4.9 & 87.5 \\
\hline $\begin{array}{l}\text { To avoid challenges at points of entry; to } \\
\text { avoid health problems }\end{array}$ & 38 & 9.9 & 97.4 \\
\hline To avoid health problems; to take vaccines & 8 & 2.1 & 99.5 \\
\hline $\begin{array}{l}\text { To avoid challenges at points of entry; to } \\
\text { take prophylaxes }\end{array}$ & 2 & 0.5 & 100.0 \\
\hline Total & 384 & 100.0 & \\
\hline
\end{tabular}

Table 6. Source of Information on Yellow Fever Guidelines

\begin{tabular}{lcc}
\hline & No. & Percent \\
\hline Kenyan government & 111 & 41.1 \\
CDC & 43 & 15.9 \\
WHO & 66 & 24.4 \\
Kenyan government/CDC & 17 & 6.4 \\
Kenyan government/WHO & 13 & 4.8 \\
WHO/CDC & 12 & 4.4 \\
Others & 8 & 3 \\
Total & 270 & 100.0 \\
\hline
\end{tabular}

than one source: $6.4 \%$ from both the Kenyan government and the CDC, $4.8 \%$ from the Kenyan government and the WHO, and $4.4 \%$ from the WHO and the CDC. Others learned about them from other sources including private doctors (Table 6).

\section{Attitude}

The majority of respondents $(90.6 \%)$ perceived vaccination as important prior to travel, while the minority (9.4\%) thought vaccination prior to travel is not important (Figure 2). Most of the respondents $(74.7 \%)$ thought it was important to visit a healthcare provider when already vaccinated, but $25.3 \%$ thought it was not important to visit a healthcare provider when already vaccinated (Figure 3 ). The majority of the respondents $(91.1 \%)$ thought that obtaining information on likely health risks prior to travel would reduce the chances of falling sick while abroad, while $8.9 \%$ perceived that obtaining information prior to travel as unlikely to reduce the chances of getting sick while abroad (Figure 4). Slightly more than a third of the respondents $(67.4 \%)$ were afraid of acquiring infections while abroad, while $32.6 \%$ were not afraid of

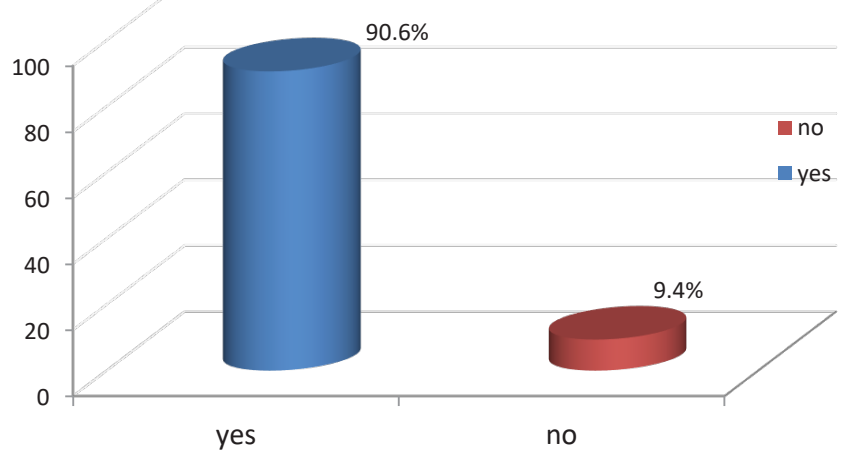

Figure 2. Perception of Importance of Vaccination Prior to Travel $(n=384)$

Do you think it is important to visit a healthcare provider when already vaccinated $(n=384)$ ?

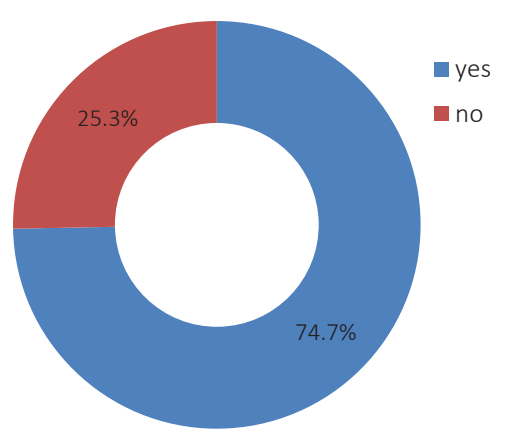

Figure 3. Perception Regarding Visiting Healthcare Providers When Already Vaccinated.

Do you think receiving information on likely health risks prior to travel reduces the chances of falling sick when abroad $(n=384)$ ?

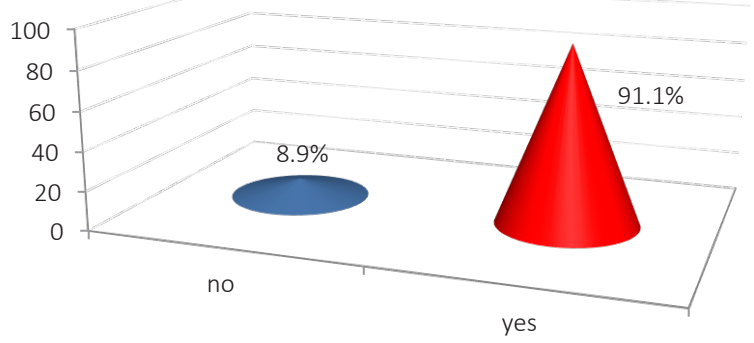

Figure 4. Perception of How Getting Information Reduces Risk of Illness While Abroad.

acquiring infections (Figure 5).

The majority of respondents $(72.4 \%)$ were satisfied with the pre-travel health services offered, while $27.6 \%$ expressed dissatisfaction (Table 7). The majority of respondents were dissatisfied with the pre-travel health services offered, because only vaccines were given. Other reasons for dissatisfaction were that no advice was given and the cost of the vaccines was high (Figure 6).

\section{Practices}

Vaccination was the most sought-after pre-travel health 
Are you afraid of acquiring new infections while abroad $(n=384)$ ?

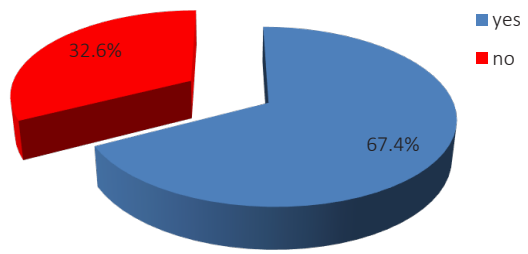

Figure 5. Perception of Risk of Acquiring Infections While Abroad.

m only vaccination is given $\quad$ no advice is given it is expensive Reasons for dissatisfaction ( $n=93)$

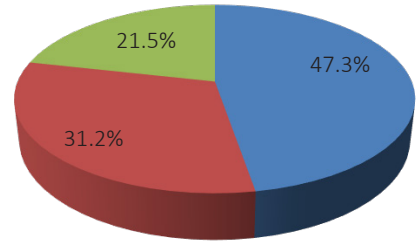

Figure 6. Reason for Dissatisfaction.

Table 7. Satisfaction on the Services Offered to International Travelers

\begin{tabular}{lccc}
\hline & No. & Percent & Cumulative Percent \\
\hline Yes & 278 & 72.4 & 72.4 \\
No & 106 & 27.6 & 100.0 \\
Total & 384 & 100.0 & \\
\hline
\end{tabular}

service. $63.2 \%$ of the respondents received vaccinations only, $7.5 \%$ got health advice on how to stay healthy abroad, and $3.2 \%$ got drugs for self-medication only. There were other travelers who utilized more than one pre-travel health service: $5.1 \%$ got health advice as well as vaccinations, $2.67 \%$ got drugs for self-medication and vaccinations, and $1.33 \%$ got drugs for self-medication, vaccinations, and information on how to stay healthy while abroad. $16.5 \%$ of the respondents did not get any health services prior to travel, while $0.5 \%$ indicated they had obtained other services, such as lung function tests (Table 8).
Table 8. Pre-travel Health Services Received by International Travelers

\begin{tabular}{|c|c|c|}
\hline $\begin{array}{l}\text { What Pre-travel Health Services Did You Receive? } \\
(\mathrm{n}=375)\end{array}$ & No. & Percent \\
\hline Vaccination & 237 & 63.2 \\
\hline $\begin{array}{l}\text { Health advice on how to stay healthy depending on the } \\
\text { destination }\end{array}$ & 28 & 7.5 \\
\hline Drugs for self-medication & 12 & 3.2 \\
\hline I never got any services & 62 & 16.5 \\
\hline $\begin{array}{l}\text { Health advice on staying healthy at destination, } \\
\text { vaccination }\end{array}$ & 19 & 5.1 \\
\hline Drugs for self-medication; vaccination & 10 & 2.67 \\
\hline $\begin{array}{l}\text { Drugs for self-medication; health advice on staying } \\
\text { healthy at destination; Vaccination }\end{array}$ & 5 & 1.33 \\
\hline Others & 2 & 0.5 \\
\hline Total & 375 & 100.0 \\
\hline
\end{tabular}

Table 9. Sources of Pre-travel Health Services

\begin{tabular}{lcc}
\hline Sources of Pre-travel Health Advice & No. & Percent \\
\hline Internet sources & 12 & 3.8 \\
Travel agent & 36 & 11.4 \\
Private clinic & 63 & 20 \\
Health insurance company & 40 & 12.58 \\
Government designated vaccination centers & 159 & 50.32 \\
General practitioners & 6 & 1.9 \\
Total & 316 & 100.0 \\
\hline
\end{tabular}

Half of the respondents obtained pre-travel health services from government designated vaccination centers, $20 \%$ from private clinics, $12.58 \%$ from health insurance companies, and $11.4 \%$ from travel agents. The fewest respondents obtained pre-travel health advice from internet sources (3.8\%) and general practitioners (1.9\%) (Table 9).

The majority of the respondents went for pre-travel health advice more than 6 weeks prior to departure. $10.68 \%$ went between 4 to 6 weeks, $8.33 \%$ between 3 to 4 weeks, $12.76 \%$ between 2 to 3 weeks, and $14.58 \%$ between 1 to 2 weeks. The least were those who sought services less than one week before departure (9.12\%). 16.4\% of the respondents never sought any pre-travel health services (Figure 7). The majority of the travelers who never sought pre-travel health advice did

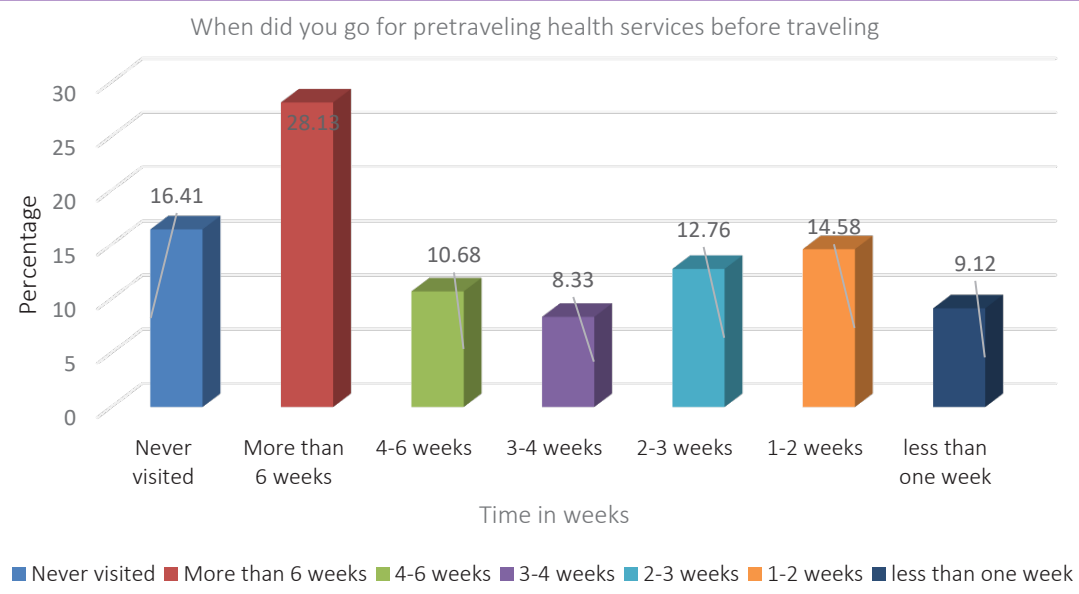

Figure 7. Time of Seeking Health Advice Prior to Departure $(n=380)$. 
Table 10. Reasons for Not Seeking Pre-travel Health Services

\begin{tabular}{lcc}
\hline $\begin{array}{l}\text { If you never got any service, what are your } \\
\text { reasons for not seeking pre-travel health } \\
\text { services? }\end{array}$ & No. & Percent \\
\hline Nobody informed me. & 4 & 6.1 \\
I got information from my family doctor. & 13 & 19.7 \\
Because I know what to do. & 26 & 39.4 \\
I don't know where to get the advice. & 19 & 28.8 \\
It is far away from me. & 3 & 4.5 \\
Other & 1 & 1.5 \\
Total & 66 & 100.0 \\
\hline
\end{tabular}

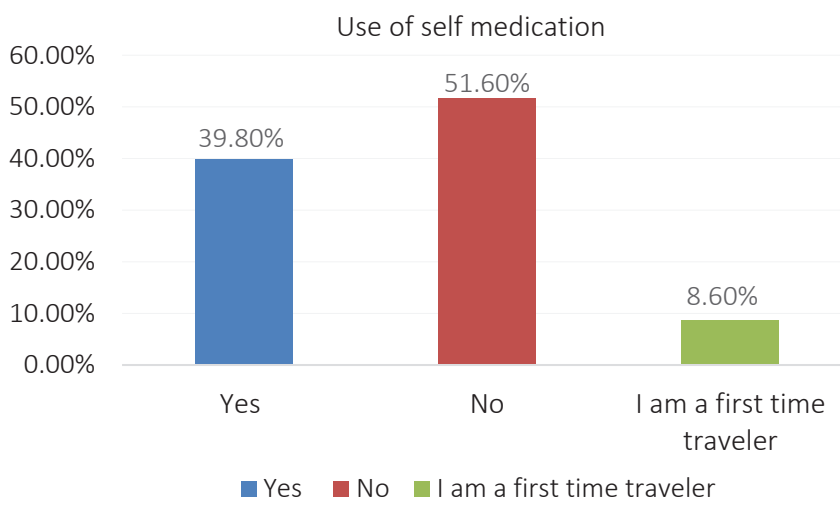

Figure 8. Use of Self-medication $(n=384)$

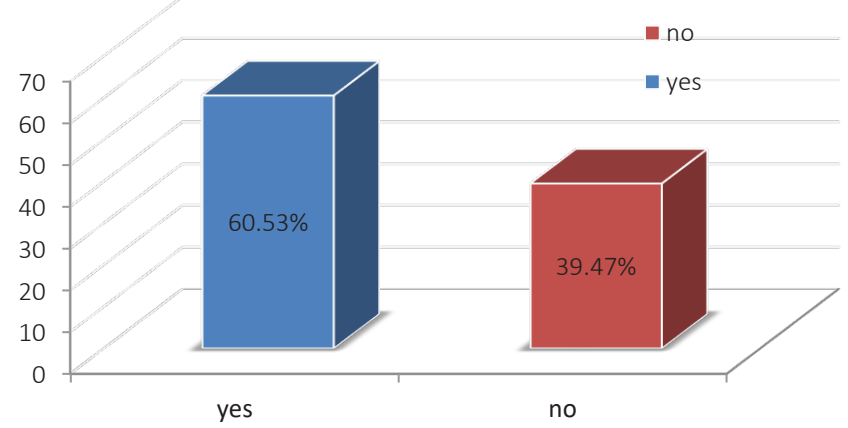

Figure 9. Immunization Status of Children $(n=38)$

so because they knew what to do when abroad, $28.8 \%$ did not know where to obtain the services, and $19.7 \%$ got the services from their family doctor. Others had nobody to inform them (6.1\%), or the place to obtain pre-travel health services was far away from them (4.5\%) (Table 10).

Slightly more than half of the respondents (51.6\%) had not used self-medication during their previous travels, while $39.8 \%$ of the respondents admitted to having used self-medication during previous travels. The rest $(8.6 \%)$ of the respondents were first-time travelers (Figure 8). 60.53\% of children traveling were fully immunized, while $15 \%$ of children traveling were not fully immunized (Figure 9). Yellow fever and hepatitis $B$ vaccines were the most common vaccines received by the respondents with $68.8 \%$ and $26.6 \%$ of total travelers interviewed, respectively. The least common
Table 11. Types of Vaccines Received by Respondents Prior to Travel

\begin{tabular}{|c|c|c|c|c|}
\hline Vaccine & $\begin{array}{c}\text { Immunization } \\
\text { Status }\end{array}$ & No. & Percent & $\begin{array}{c}\text { Cumulative } \\
\text { Percent }\end{array}$ \\
\hline \multirow{2}{*}{ Cholera } & No & 304 & 79.2 & 79.2 \\
\hline & Yes & 80 & 20.8 & 100.0 \\
\hline \multirow{2}{*}{ Yellow fever } & No & 120 & 31.3 & 31.3 \\
\hline & Yes & 264 & 68.8 & 100.0 \\
\hline \multirow{2}{*}{ Hepatitis A } & No & 313 & 81.5 & 81.5 \\
\hline & Yes & 71 & 18.5 & 100.0 \\
\hline \multirow{2}{*}{ Hepatitis B } & No & 282 & 73.4 & 73.4 \\
\hline & Yes & 102 & 26.6 & 100.0 \\
\hline \multirow{2}{*}{ Polio } & No & 333 & 86.7 & 86.7 \\
\hline & Yes & 51 & 13.3 & 100.0 \\
\hline \multirow{2}{*}{ Tetanus } & No & 340 & 88.5 & 88.5 \\
\hline & Yes & 44 & 11.5 & 100.0 \\
\hline \multirow{2}{*}{ Typhoid } & No & 339 & 88.3 & 88.3 \\
\hline & Yes & 45 & 11.7 & 100.0 \\
\hline \multirow{2}{*}{ Influenza } & No & 349 & 90.9 & 90.9 \\
\hline & Yes & 35 & 9.1 & 100.0 \\
\hline \multirow{2}{*}{ Measles/mumps/rubella } & No & 348 & 90.6 & 90.6 \\
\hline & Yes & 36 & 9.4 & 100.0 \\
\hline
\end{tabular}

vaccine was for influenza; only $9 \%$ of respondents had received it (Table 11).

Factors Affecting Utilization of Pre-travel Health Advice The odds of deciding to seek pre-travel health services were 5.66 times higher for men than for women. The odds ratio given by the model shows that the odds of seeking pre-travel health services for single people compared to those who were married was 3.8. This indicates that single people were 3.8 times more likely to seek pre-travel health services than married people. Married subjects were 1.9 times more likely to seek pre-travel health services than those who were separated. Those who were educated up to a secondary school level were 2.9 times more likely to seek pre-travel health services than those who never attended school. Those who went up to secondary school were 1.3 times more likely to seek pretravel health advice than those who held first degrees. Those who held a first degree were 2.5 times more likely to seek pretravel health services than those who held a second degree. The odds of one with a history of previous travel seeking pretravel health services were 1.51, and the odds of one with no history of previous travel seeking pre-travel health advice were 1.602. The odds of seeking pre-travel health advice for those with a history of previous travel compared with those with no history of previous travel were 1 . This means that there was no significant variation regarding seeking pre-travel health services between those who had traveled before and those who had never traveled. Those who were visiting Europe were the most likely to seek pre-travel health advice followed by those visiting the Middle East. Those visiting Europe were 1.4 times more likely to seek pre-travel health services compared with those visiting the Middle East. Those visiting Europe were 4.5 times more likely to seek pre-travel health services compared with those visiting Asia, those visiting Europe were 4 times more likely to seek pre-travel health services compared with those visiting Africa, and those visiting Europe were 1.9 times 
more likely to seek pre-travel health services compared with those visiting America.

If a respondent were visiting friends and relatives, the odds of seeking pre-travel health services were 2.75 . If the subjects were going for vacation/tourism, the odds of seeking pre-travel health services were 16.53. If a subject's reason for travel was business/convention or conferences, the odds of seeking pre-travel health services were 1 . If the reason for travel was research, the odds that the respondent would have sought pre-travel health services were 2.66. For those going for missionary work, the odds that they would have sought pre-travel health services were 1.09 , and for those who were going for healthcare, the odds that they would have sought pre-travel health advice were 10.72. From the model, those going for vacation/tourism were the most likely to seek pretravel health services followed by those going for medical care/ procedure. Those going for business/convention/conferences or mission work were the least likely to seek pre-travel health advice. Respondents between 36 and 50 years of age were 1.6 times more likely to seek pre-travel health services compared with those between the ages of 18 and 35. Those travelers whose duration of stay was between 2 weeks and 3 months were the most likely to seek pre-travel health services; they were 2.5 times more likely to seek pre-travel health advice than those whose duration of stay was less than two weeks and 1.5 times more likely to seek pre-travel health services compared with those whose duration of stay was more than 3 months. Those visiting only one country were 2.356 times more likely to seek pre-travel health services compared with those visiting two countries or more (Table 3 ).

Availability of Pre-Travel Health Services in Kenya (Qualitative Results)

Table 12 shows key themes from key informants' interviews.

\section{Discussion}

Knowledge, Attitude, And Practices of Respondents With Regard to Seeking Pre-travel Health Services

Knowledge

The majority of respondents (70.6\%) knew of at least one health service offered to international travelers in Kenya. However, $29.4 \%$ were not aware of such health services. $84.2 \%$ of those who knew of services offered to international travelers knew only of vaccinations. Only $11.28 \%$ were aware of the availability of health advice, which was lower than the rate of $48 \%$ reported in a study conducted in the Doha, Qatar International Airport. ${ }^{5}$ In addition, only $4.14 \%$ of the study participants were aware of drugs for self-medication as a pre-travel health service. When asked about the importance of pre-travel health services, the majority of respondents associated it with avoiding health problems $(71.9 \%)$ and challenges at points of entry (21.1\%). In a study among Dubai travelers, the majority of the respondents (95\%) were aware of the importance of pre-travel health services in avoiding health problems when abroad. ${ }^{6}$ In this study, $4.9 \%$ of the respondents did not know the importance of vaccinations.

$70.53 \%$ of travelers were aware of existing travel recommendation guidelines. The most common sources of guidelines were the Kenyan government $(52.3 \%)$ and the WHO (29.2\%). This contradicts what was said by the key informant interviewees who said that Kenya has no guidelines itself but uses standard operating procedures derived from the WHO guidelines.

\section{Attitude}

Generally, travelers had a positive attitude towards pre-travel health services. $90.6 \%$ of the respondents recognized the importance of vaccinations. From the study, $70.97 \%$ actually went for vaccinations. This is in line with a study conducted

Table 12. Key Themes From Key Informants' Interviews

\begin{tabular}{|c|c|}
\hline Theme & Responses \\
\hline $\begin{array}{l}\text { What are the major pre-travel health services offered } \\
\text { at JKIA? }\end{array}$ & $\begin{array}{l}\text { "I am not sure we do much for travelers departing beside vaccinating against yellow fever or polio, but } \\
\text { advice is given upon request. The traveler has to initiate," (female, } 35 \text { years old). }\end{array}$ \\
\hline Are there specific services offered to specific groups? & $\begin{array}{l}\text { "There are no specific services for specific groups. At times we talk to athletes prior to departure," } \\
\text { (male, } 55 \text { years old). } \\
\text { "The only group of people I can categorize as special are those going for Hajj; otherwise, I can't think } \\
\text { of any other," (female, } 43 \text { years old). }\end{array}$ \\
\hline $\begin{array}{l}\text { What avenues do you use to reach out to travelers } \\
\text { with pre-travel health services? }\end{array}$ & $\begin{array}{l}\text { "That's a bit hard, because we, as port health officers, do not often interact with departing passengers. } \\
\text { Our focus is more on arriving passengers due to the risk they pose to the country in case they come in } \\
\text { with an infectious disease," (female, } 45 \text { years old). }\end{array}$ \\
\hline $\begin{array}{l}\text { Is there a structure through which a traveler can get } \\
\text { information from various institutions? }\end{array}$ & $\begin{array}{l}\text { "There are no structures that I know of," (male, } 55 \text { years). } \\
\text { "Structures are there for international travelers arriving into the country, but not those departing to other } \\
\text { countries," (female, } 35 \text { years old). }\end{array}$ \\
\hline $\begin{array}{l}\text { What institutions are involved in providing pre-travel } \\
\text { health advice? }\end{array}$ & $\begin{array}{l}\text { "There are no other institutions involved; this is the mandate of the Port Health Department under the } \\
\text { Ministry of Health," (female, } 43 \text { years old). }\end{array}$ \\
\hline $\begin{array}{l}\text { How do you encourage travelers to visit health clinics } \\
\text { prior to travel? }\end{array}$ & $\begin{array}{l}\text { "We do not often visit the terminals where departing passengers are handled. However, whenever we } \\
\text { meet travel agents, we request that they ensure travelers are vaccinated depending on their destination," } \\
\text { (female, } 35 \text { years old). }\end{array}$ \\
\hline $\begin{array}{l}\text { Do you think the avenues used to reach out to } \\
\text { travelers with healthcare information prior to travel } \\
\text { are adequate? }\end{array}$ & $\begin{array}{l}\text { "We focus on the passengers arriving from other destinations due to the risk involved to the country as } \\
\text { a whole, but it is also important that the Kenyan government puts up measures to protect the health of } \\
\text { its citizens," (female, } 43 \text { years old). } \\
\text { "It's not adequate. Information is passed through a third party, and hence can be easily distorted. } \\
\text { Additionally, travelers in this category are always in a hurry; hence, talking to them during that time is } \\
\text { mostly perceived as an inconvenience," (male, } 55 \text { years old). }\end{array}$ \\
\hline
\end{tabular}


among Dubai travelers in which $96.2 \%$ perceived vaccinations to be important. ${ }^{6}$ In this study, it was found that only $32 \%$ of travelers would visit a healthcare provider when already vaccinated. This result was contrary to those of the current study where three quarters $(74.7 \%)$ of the respondents indicated it is important to visit a healthcare provider even when already vaccinated.

The majority of respondents $(91.1 \%)$ said that receiving information on likely health risks prior to travel reduces the chances of falling sick while abroad. This means that despite as few as $13.93 \%$ obtaining pre-travel health advice, the respondents perceived it as important. Reduced risk perception translates to negative health-seeking behavior. $32.6 \%$ of the respondents were not afraid of acquiring new infections when abroad. Poor risk perception was also reported in a similar study in Doha, Qatar. ${ }^{5}$

About $28 \%$ of the respondents were not satisfied with the pre-travel health services given. The reasons for dissatisfaction were that only vaccinations were given $(47.3 \%)$, no advice was given $(31.2 \%)$, and it was expensive $(21.5 \%)$. In the case of the study in Qatar, 32.4\% of travelers were not satisfied and the single cause of dissatisfaction reported by the majority of respondents (33.3\%) was that only some advice was given.

\section{Practices}

Variations exist in the pre-travel health-seeking behavior of travelers in relation to the existing published literature. Based on this study, while only $16.5 \%$ of all respondents never got any health services prior to departure, pre-travel health advice was obtained by only $13.93 \%$ of respondents. This is slightly below the $22.5 \%$ obtained by a similar study conducted at Muscat International Airport. ${ }^{7}$ A similar study among Australian travelers found that only $31 \%$ of respondents sought pre-travel health advice. ${ }^{8}$ Almost three quarters (70.97\%) of respondents indicated they had received at least one vaccine for purposes of travel. Carrying drugs for self-medication was not a common practice among respondents, since less than one tenth (7.2\%) had drugs for self-treatment in case of a health problem while abroad. Elsewhere, a study among travelers in the United States showed that, although $73 \%$ of respondents traveling to malaria endemic regions perceived themselves as susceptible, only $46 \%$ went for antimalarial medications, and only $5 \%$ of respondents went for a yellow fever vaccine. ${ }^{9}$

The most common source of pre-travel health advice among respondents was government designated centers where half $(50.32 \%)$ of the respondents sought pre-travel health services. Health insurance companies, travel agents, private clinics, and general practitioners were other mentioned sources that were less popular among the respondents. The results indicated there is an under-utilization of the Internet (3.5\%) in the acquisition of pre-travel health services despite key informant interviews revealing a lack of adequate avenues to pass information to departing international travelers. This is contrary to the study in 2010, where the Internet and primary healthcare workers were the most common sources of pre-travel health services and advice. ${ }^{10}$ A different study revealed that approximately one third of respondents went for health services only within two weeks of departure, ${ }^{11}$ while in the current study, $23.74 \%$ sought health services within 2 weeks prior to departure. This poses a risk of traveling before acquiring immunity, since some vaccines need as much time as 10 days as in the case of the yellow fever vaccine.

Time has been reported in other studies as a reason for failing to seek pre-travel health services ${ }^{12}$; in the current study, $39.8 \%$ of respondents who did not seek pre-travel health services said they knew what to do. Slightly more than half of the respondents (51.6\%) had not used self-medication during their previous travels. This could either mean they had never fallen ill or they had not carried any drugs for self-treatment. More than half of the respondents (60.53\%) traveling with children had the children fully immunized prior to departure. The most common sought-after vaccines among respondents were yellow fever $(68.8 \%)$ and hepatitis B $(26.6 \%)$, while the least common among the respondents was influenza (9.1\%). The time that had elapsed since a respondent received a vaccine and the time they participated in this study made this data subject to recall bias, because it was self-reported.

\section{Factors Associated With the Utilization of Pre-travel Health Services}

The odds of deciding to seek pre-travel health services were 5.66 times higher for men than they were for women. For men, the odds were 62.3 , while for women they were 11 . This is in line with the results of a study conducted in Dubai, UAE in which being male was more greatly associated with visiting a travel clinic than being female. ${ }^{6}$

When marital status was assessed, the odds of a single person seeking pre-travel compared with a married person was 3.8. This indicated that single people were 3.8 times more likely to seek pre-travel health services than married people. This is similar to the results of a study done among travelers departing Sydney and Bangkok airports in which a married traveler was 1.81 times more likely to seek travel health services than one who was married..$^{13}$ Married subjects were 1.9 times more likely to seek pre-travel health services than those who were separated.

Those who were educated up to a secondary school level were 2.9 times more likely to seek pre-travel health services than those who never attended school. This is in line with a study conducted in Doha, Qatar in which having gone up to secondary school was associated with higher uptake of pretravel health services. ${ }^{5}$ Beyond secondary school, the rate of uptake of pre-travel health services decreased with increases in the level of education. Those who went up to secondary school were 1.3 times more likely to seek pre-travel health advice than those who held a first degree. Those who held a first degree were 2.5 times more likely to seek pre-travel health services than those who held a second degree.

Having a history of previous travel did not in any way affect pre-travel health services-seeking behavior. The odds of seeking pre-travel health advice with a history of previous travel compared with the odds with no history of previous travel were 1 . That means that there was no significant variation in seeking pre-travel health services between 
those who had previously traveled and those who had never traveled.

Destination was seen to influence the pre-travel health services-seeking behavior of respondents. Those visiting Europe were 1.4 times more likely to seek pre-travel health services than those visiting the Middle East. Those visiting Europe were 4.5 times more likely to seek pre-travel health services than those visiting Asia. Those visiting Europe were 4 times more likely to seek pre-travel health services than those visiting Africa, and those visiting Europe were 1.9 times more likely to seek pre-travel health services than those visiting America. Those going for vacation/tourism were the most likely to seek pre-travel health services followed by those going for medical care/procedure. Those going for business/ convention/conferences or mission work were the least likely to see pre-travel health advice. Equally, business travelers were reported to be 2.38 times less likely to seek health advice by a study conducted in the Sydney and Bangkok airports. ${ }^{13}$ In addition, a study conducted among Spanish travelers showed that tourists were more likely to be vaccinated than business travelers. ${ }^{14}$

Age was an important predictor of pre-travel health services-seeking behavior. Respondents were more likely to seek pre-travel health services as their aged increased. If a respondent was between 36 and 50 years of age, they were 1.6 times more likely to seek pre-travel health services compared with those between the ages of 18 and 35. Equally, the study conducted at the Bangkok airport showed that the odds of seeking pre-travel health services increased as the age of the respondents increased.

Those travelers whose duration of stay was between 2 weeks and 3 months were the most likely to seek pre-travel health services; they were 2.5 times more likely to seek pre-travel health advice than those whose duration of stay was less than two weeks. Additionally, those whose duration of stay was less than two weeks, were 1.5 times more likely to see pre-travel health services compared to those whose duration of stay is more than 3 months.

The results indicated that the number of countries being visited by the respondents was a predictor for seeking pretravel health services. Respondents visiting only one country were 2.356 times more likely to seek pre-travel health services than those visiting two countries or more. Contrary to this finding of the current study, the study conducted at the Bangkok airport showed that respondents visiting two or more countries were 2.38 times more likely to seek pre-travel health services than those visiting one country. ${ }^{13}$

\section{Availability of Pre-travel Health Services}

The provision of pre-travel health services involves 5 elements, namely: assessing the traveler's personal health status, assessing the risks involved in the anticipated trip, preventive advice, suitable vaccinations, and health assessment posttravel.

The major pre-travel health services offered to departing international travelers were indicated as vaccinations, treating those who had fallen sick prior to departure, and health education to travelers who go for inquiries. Vaccinations available for travelers at JKIA were the yellow fever lifetime vaccine for those traveling to endemic regions at a cost of 3500 ksh and the polio vaccine given once every year to travelers going to India at a cost of $1000 \mathrm{ksh}$. One respondent noted:

"I am not sure we do much for departing travelers other than vaccination against yellow fever or polio, but advice is given upon request. The traveler has to take the initiative. We also give medical assistance in case a traveler falls ill just before departure" (female, 35 years old).

Apart from travelers going for hajj, there are no special groups or categories of travelers, but there are groups of people such as lactating and pregnant women and the immunosuppressed who are exempt from the yellow fever vaccine due to the risks involved. During travel, those groups receive a yellow fever exemption certificate. One participant observed:

"The only group of people I can categorize as special are those going for hajj; otherwise, I can't think of any other" (female, 43 years old).

According to the key informants, the Port Health Department at JKIA is mainly focused on securing the country from the introduction of diseases by arriving passengers as opposed to protecting Kenyans leaving to other countries due to staff shortages. In reality, whether a departing traveler gets pre-travel health advice or not is entirely dependent on whether or not they take the personal initiative.

"That's a bit hard, because we as Port Health officers do not often interact with departing passengers. Our focus is more on arriving passengers due to the risk they pose to the country in case they come in with an infectious disease" (female, 45 years old).

There are no established structures from which departing travelers can get all the health services they need, especially information. As in the case of a disease outbreak, information is passed through various existing airport committees during meetings. The limitation with this is that when third parties are involved, the information is at higher risk of being distorted or not being emphasized as it should be when being passed to the travelers.

"There are no structures that I know of" (male, 55 years old).

When the key informants were asked if there were other institutions offering pre-travel health services, they all agreed that apart from the Port Health Department under the Ministry of Health, no other institution is mandated.

"There are no other institutions involved, this is the mandate of the Port Health Department under the Ministry of Health" (female, 43 years old).

The informants highlighted that the avenues used to reach travelers with pre-travel health advice are inadequate as little attention is paid to departing international travelers.

"It's not adequate. Information is passed through a third party; hence, it can be easily distorted" (male, 55 years old).

\section{Conclusion}

This study concludes the following:

Pre-travel health services available to international travelers departing from Kenya are inadequate. Apart from vaccinations obtained from government designated centers, there are no 


\section{Research Highlights}

\section{What Is Already Known?}

The global transportation network provides epidemic pathways for the dissemination of infectious diseases such as yellow fever and Ebola. Although pre-travel health consultation reduces the risk of harm as a result of exposure to hazards while abroad, a number of surveys have shown that high proportions of travelers disregard their travel health risks.

\section{What This Study Adds?}

There are no previous studies on pre-travel health services in Kenya. This study offers insights into the current state of travel medicine in Kenya and creates awareness on the need for further research around this topic not only in Kenya but across the African continent. In addition, after publication the results of the study will create awareness among international travelers on the need to take up pretravel health services available. This will increase uptake of pre-travel health consultations hence reducing chances of travelers acquiring infections.

structures to guide the provision of pre-travel health advice or drugs for self-medication. Kenya focuses more on arrivals as opposed to departures; hence, those leaving the country do not access adequate health services which may also pose a threat to public health in destination countries.

Pre-travel health advice was the least popular pre-travel health service among Kenyan international travelers despite its importance in ensuring preparedness for the trip as well as passing knowledge to travelers on how to react in case of illness while abroad. Generally, the study showed that travelers had a positive attitude towards pre-travel health services. With regard to practice, the majority of travelers go for at least one pre-travel health service, which was in most cases vaccination. Although technology is being incorporated in every sector, the Internet as a source of pre-travel health advice is still underutilized. Factors such as gender, marital status, level of education, travel destination, reasons for travel, age, duration of stay, and number of countries being visited were found to be independent predictors of seeking pretravel health services. There were no significant variations in seeking pre-travel health services between those who had traveled before and those who had never traveled.

\section{Authors' Contributions}

All authors contributed equally to this study.

\section{Conflicts of Interest Disclosures}

The authors declare that there is no conflict of interest.

\section{Ethical Approval}

The present study was approved by the KNH/UON ethical review board. The ethical approval code for this study was P126/03/2017. During research, informed consent was sought from the study participants, and those unwilling to participate in the research process were not compelled to do so. This research was non-invasive, and the data collection forms did not bear the name of the respondents; they were identified by a study identity code number. Respondents' data was used with strict confidentiality and for the sole purpose of meeting the objectives of this study. All data will be destroyed after the study is published and the researcher has graduated. No direct benefits or incentives were given to participants in the research.

\section{Funding/Support}

None.

\section{References}

1. Kenya National Bureau of Statistics. Kenya facts and figures. https://www.knbs.or.ke/download/kenya-facts-2015/.

2. Field V, Gautret $P$, Schlagenhauf $P$, et al. Travel and migration associated infectious diseases morbidity in Europe, 2008. BMC Infect Dis. 2010;10:330. doi:10.1186/1471-2334-10-330.

3. Leggat PA. Sources of health advice given to travelers. J Travel Med. 2000;7(2):85-88.

4. Askling HH, Nilsson J, Tegnell A, Janzon R, Ekdahl K. Malaria risk in travelers. Emerg Infect Dis. 2005;11(3):436-441. doi:10.3201/ eid1103.040677.

5. Al-Hajri M, Bener A, Eljack I, Balbaid O. Travellers Knowledge, Attitudes and Practices on the Prevention of Infectious Diseases: Qatar-Doha International Airport Study. Middle East Journal of Family Medicine. 2011;9(9):22-28.

6. Omer F, Hassan N, Hussain H, Mana S, Awad O. Travel health, gaps in knowledge, attitudes, and practices among Dubai travellers, Dubai UAE. Int J Prev Med Res. 2015;1(3):126-131.

7. Al-Abri SS, Abdel-Hady DM, Al-Abaidani IS. Knowledge, attitudes, and practices regarding travel health among Muscat International Airport travelers in Oman: Identifying the gaps and addressing the challenges. J Epidemiol Glob Health. 2016;6(2):6775. doi:10.1016/j.jegh.2016.02.003.

8. Wilder-Smith A, Khairullah NS, Song JH, Chen CY, Torresi J. Travel health knowledge, attitudes and practices among Australasian travelers. J Travel Med. 2004;11(1):9-15.

9. Hamer DH, Connor BA. Travel health knowledge, attitudes and practices among United States travelers. J Travel Med. 2004;11(1):23-26.

10. LaRocque RC, Deshpande BR, Rao SR, et al. Pre-travel health care of immigrants returning home to visit friends and relatives. Am J Trop Med Hyg. 2013;88(2):376-380. doi:10.4269/ ajtmh.2012.12-0460.

11. Zwar N, Streeton CL. Pretravel advice and hepatitis A immunization among Australian travelers. J Travel Med. 2007;14(1):31-36. doi:10.1111/j.1708-8305.2006.00088.x.

12. Ropers G, Du Ry van Beest Holle M, Wichmann O, et al. Determinants of malaria prophylaxis among German travelers to Kenya, Senegal, and Thailand. J Travel Med. 2008;15(3):162-171. doi:10.1111/j.1708-8305.2008.00188.x

13. Heywood AE, Watkins RE, lamsirithaworn S, Nilvarangkul K, Maclntyre CR. A cross-sectional study of pre-travel health-seeking practices among travelers departing Sydney and Bangkok airports. BMC Public Health. 2012;12:321. doi:10.1186/1471-2458-12321.

14. Lopez-Velez R, Bayas JM. Spanish travelers to high-risk areas in the tropics: airport survey of travel health knowledge, attitudes, and practices in vaccination and malaria prevention. J Travel Med. 2007;14(5):297-305. doi:10.1111/j.1708-8305.2007.00142.x. 